\title{
Effect of Variability in Rainfall Characteristics on Maize Yield in Gboko, Nigeria
}

\author{
Emmanuel Msughter Adamgbe ${ }^{1}$, Fanan Ujoh $^{2}$ \\ ${ }^{1}$ Department of General Studies, Akperan Orshi College of Agriculture, Yandev, Nigeria; ${ }^{2}$ Department of Urban and Regional Plan- \\ ning, Benue State University, Makurdi, Nigeria. \\ Email: fananujoh@gmail.com
}

Received June $13^{\text {th }}, 2013$; revised July $18^{\text {th }}, 2013$; accepted August $10^{\text {th }}, 2013$

Copyright (C) 2013 Emmanuel Msughter Adamgbe, Fanan Ujoh. This is an open access article distributed under the Creative Commons Attribution License, which permits unrestricted use, distribution, and reproduction in any medium, provided the original work is properly cited.

\begin{abstract}
The study examines the impact of variability in rainfall characteristics on maize yield in a tropical setting. The study design involves the collection and analyses of data on rainfall characteristics and maize yield at Gboko LGA in Benue State, Nigeria. The methodology adopted is the use of archival data on rainfall and maize yield for 30 years, collected from the Agro-Meteorological Unit and Farm Department of Akperan Orshi College of Agriculture, Yandev (AOCAY). The data was analyzed using mean, correlation and regression analysis to establish cause and effect relationship between rainfall characteristics and maize yield at the study area. The result of the correlation analysis showed that rain days and rainfall amount had strong positive relationship $(r=0.747$ and $r=0.599$, respectively) with maize yield. It was also observed that the rainfall characteristics jointly contributed $67.4 \%$ in explaining the variations in the yield of maize per hectare. The study concludes with the development of a model for predicting maize yield in Gboko LGA. The study also recommended the application of irrigation technology, use of appropriate management practices that ensured moisture conservation and improved crop species with shorter growing periods/less moisture consumption as adaptive measures to the changing rainfall pattern within the study area.
\end{abstract}

Keywords: Rainfall Variability; Onset and Cessation; Duration; Rain Days; Rainfall Amount; Maize Yield

\section{Introduction}

Climate variability and change has become a topical issue in recent time because of its largely detrimental impacts on natural and human systems. The most frequently cited activities/operations likely to be affected by climate variability and change are agriculture, forestry, hydrology and fisheries [1].

Agriculture which is the mainstay of local livelihoods and national Gross Domestic Product (GDP) in some African countries [2] is the most vulnerable to climate variability and change. This is because in spite of recent technological advances, weather and climate are still the most important variables in agricultural production [3]. As such, its production processes, whether for food, fibre, beverages, energy, and industrial production or for livestock, poultry or fisheries, will be heavily affected by climate variability and change. Increasing weather variability affects the suitability of land for different types of crops and pasture. The health of animals and their productivity as well as incidence of pests and diseases, loss of arable land due to increased drought, aridity, and ground water depletion may result from climate variability.

The major impacts of climate variability on agricultural production will come from changes in temperature, rainfall, ultra violet (UV) radiation, and carbon dioxide $\left(\mathrm{CO}_{2}\right)$ levels. These in addition to long term shifts in seasonal climatic patterns and increases in the frequency and intensity of weather extremes are already disrupting agriculture. It is observed that variability in rainfall characteristics has the potential to influence crop production significantly [4]. Therefore, countries of the SubSaharan Africa like Nigeria with predominantly rural economies and low levels of agricultural diversification are at greater risk. Moreover, a large proportion of their population depends on rain-fed agriculture whereas their capacities (technological, financial, political and social) both at national and local levels to adapt to the changing climatic conditions are low. Climate predictions and analysis of past and current trends indicate that small- 
scale farming households in the tropical and subtropical areas will be exposed to increased climate risks and will become more and more vulnerable to these risks [5]. As a result, the production of the principal crops like rice, wheat, maize, and sorghum in the past few decades have continued to decline while the population increases [6]. This scenario increases the risk of hunger and food insecurity thereby placing a heavy reliance on food aid at the national and household levels.

Meeting this challenge requires drastic increase in the productivity of the principal staples especially maize which is a very important staple food crop in the SubSaharan African region, and Nigeria in particular. Maize (Zea mays) is a source of food for man, and feed for livestock. In many parts of West Africa, it is a staple food for the masses and also provides dry season feed for farm animals. Maize is an important source of carbohydrate, protein, iron, vitamin $B$, and minerals. Green maize (fresh on the cob) is eaten parched, baked, roasted or boiled, and plays an important role in filling the hunger gap after the dry season. Consequently, maize has a lot of comparative advantages and more than any other crop, offers the promise of meeting Africa's food needs as no other cereal can be used in as many ways as maize. However, the yield of maize has continued to be very low particularly in Benue state which has a lot of potentials for crop production (including maize) and is regarded as the "Food Basket of the Nation".

The low yield of crops particularly maize in Benue State can be attributed to several factors such as pressure on land due to population growth and attendant declining size of farm holdings, migrations, ethnic conflicts, inability of the peasant farmers to access fertilizers, conservative attitudes towards extension services, and market forces that are disincentives [6]. Others include field operations, timing of planting, pests and diseases, soil, and superimposed on these is climate [7]. Of the climatic elements, rainfall, temperature and potential evaporation are the most critical in crop production [3]. However, rainfall has more significant effect on inter-annual changes in crop yield in a tropical environment as it determines the supplies of water to plants [6]. Moreover, rainfall is the major limiting climatic factor in the growth and production of crops [8] as it is particularly very sensitive to water deficit. Moreover, rainfall is the most variable of all climatic elements and determines the growing season in developing countries like Nigeria where agriculture is predominantly rain-fed. Almost every farmer is interested in what the expected rainfall would be, more than any other climatic element as it determines the success or failure of crops.

In Benue State, generally there is high variability of rainfall. The rainfall has been characterized by pronounced variability from year to year and place to place. The onset of effective rainy season seems to have been delayed in an unpredictable manner in recent years without delay in cessation. The duration of rainy season (length of growing season) as well as the annual amount/distribution and number of rain days also vary significantly. This variable weather pattern has serious repercussion for the inhabitants as it seriously truncates all efforts being put in place by both individuals, local, state and federal governments to ensure agricultural viability, abundant food supply and food security in the state. As a result, "the food basket of the nation" status is gradually dwindling largely due to the variable weather. Attempts by previous studies on rainfall and crop yield in the state [9, 10] were based on some rainfall characteristics such as dates of onset and end of rainy season, annual amount and temperature. Though these studies were comprehensive, important rainfall characteristics like duration and rain days that were also vital to crops were not considered. It is against this backdrop that this study focuses on examining the variability in rainfall and its effect on maize yield in Gboko LGA of Benue State with a view to suggesting appropriate adaptive management mechanisms to cope with the rainfall variability.

\section{Materials and Methods}

\subsection{Study Area}

Gboko LGA is located in the north-eastern part of Benue State between latitudes $7^{\circ} 13^{\prime} \mathrm{N}$ and $7^{\circ} 35^{\prime} \mathrm{N}$, Longitudes $8^{\circ} 30^{\prime} \mathrm{E}$ and $9^{\circ} 03^{\prime} \mathrm{E}$. The Agro-meteorological station where the rainfall data was collected lies on Latitude $7^{\circ} 26^{\prime} \mathrm{N}$ and Longitude $8^{\circ} 55^{\prime} \mathrm{E}$. Gboko LGA is bordered to the north by Tarka and Buruku LGAs, to the South by Konshisha LGA, to the west by Gwer LGA and to the south-east by Ushongo LGA. It comprises of five districts which include: Mbatierev, Mbayion, Mbatiav, Yandev and Ipav (Figures 1 and 2).

The area experiences the Aw tropical wet and dry climate type. Rainfall occurs between April to October with maximal peaks in July and September while the dry season occurs between November and March. Mean annual rainfall is about $1300 \mathrm{~mm}$ per annum. Mean monthly temperature ranges between $25^{\circ} \mathrm{C}$ to $30^{\circ} \mathrm{C}$ with February and March being the hottest months while relative humidity is about $75 \%$. The relief of the area consists generally of rolling plains with Mkar Hills to the east and Gboko Hills to the north. The area is drained by the several streams and rivers including Kontien, Ahungwa, Ambor, Ngo, Ngu-embi and the head stream of River Konshisha. The main soil type in the study area is tropical ferruginous. It is generally well drained, low in organic matter, bases and cation exchange capacity [11]. Also, hydromorphic soils are found along the major streams and river courses. These soils are generally suit- 


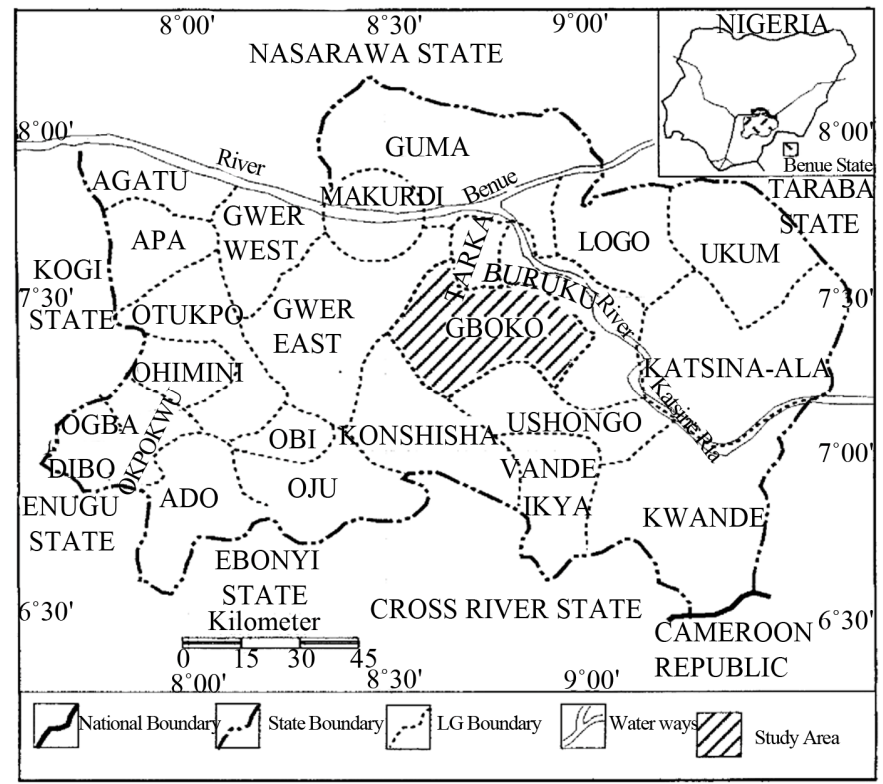

Figure 1. Map of Benue State showing Gboko LGA.

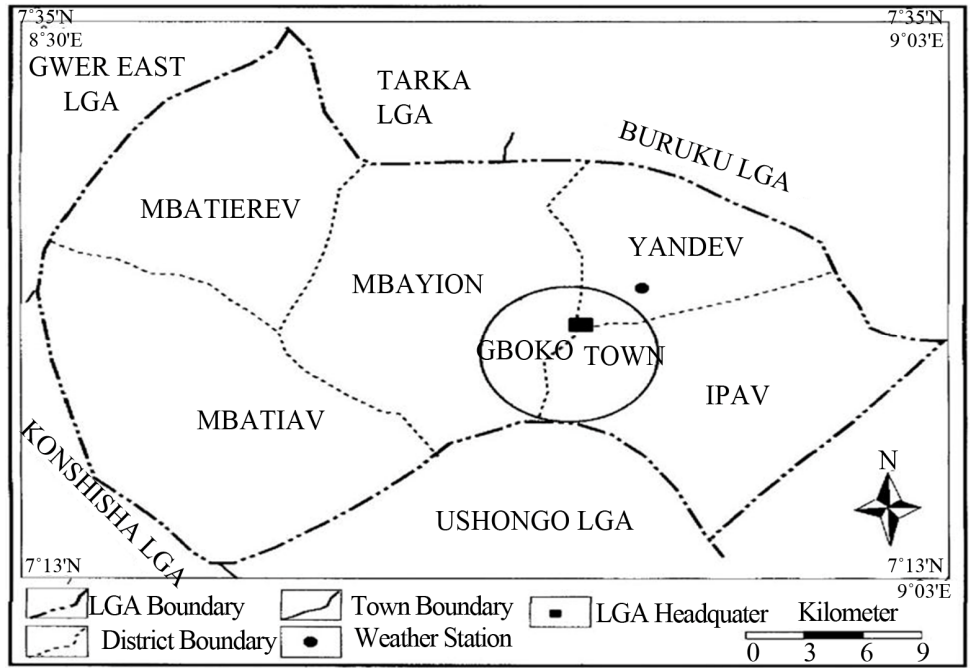

Figure 2. Map of Gboko LGA showing weather station.

able for the cultivation of certain crops including maize.

The people in the study area are Tiv and predominantly farmers who specialize in the cultivation of crops such as yams, cassava, maize, guinea-corn, tomatoes, pepper, rice, citrus, mango and cashew $[9,10]$. Farming is climate-dependent, especially on rainfall. Climate influences all farming activities in the area, hence crop production takes place within the rainy season.

\subsection{Study Materials and Analyses Methodology}

The data used for this study were archival data on rainfall (in millimeters) and maize yield (in kilograms/hectare). The data on annual maize yield (kg) for 30 years (1980-2009) was collected from the Farm Department of
Akperan Orshi College of Agriculture, Yandev. From this, the mean yield in kilograms per hectare was derived by dividing the total yield for each year by the land area cultivated. This was to avoid variations in maize yield attributable to variations in the land area cultivated. The variety/specie of maize upon which this study was based is the "Oba Super 2-white" which has been cultivated over the years by the College Farm Department in plots on annual rotational basis. The choice of this single variety was to ensure consistency and avoid variations arising from the application of multiple varieties over the years.

Data on daily rainfall (from which monthly and annual values were derived) was collected over 30 years (19802009) from the official records of the Agro-Meteoro- 
logical Unit of AOCAY. The choice of this length of time is in line with the convention of using 30 years' weather data in characterizing the climate of an area, as adopted by the World Meteorological Organization.

From the rainfall data collected, the following parameters were derived/determined:

- Date(s) of onset of the rainy season (in days);

- Date(s) of end of the rainy season (in days);

- Duration of the rainy season (in days);

- Annual number of rain days (in days); and,

- Annual rainfall amounts (in $\mathrm{mm}$ ).

There are several methods of computing onset, end and duration of the rains such as [12-14]. However, Walter's formulation as modified by Olaniran [15] was adopted in this study because of its high prediction reliability among other methods [16]. The method is expressed as:

$$
\text { Date of Onset } / \text { End }=D M \frac{51-A}{T M}
$$

where;

$D M=$ the number of days in the month containing the date of Onset/End;

$A=$ the accumulated total rainfall of the previous months;

$T M=$ the total rainfall for the month in which $51 \mathrm{~mm}$ or more is reached and

$51 \mathrm{~mm}=$ the threshold of rainfall for both Onset/End month.

Where such onset date was followed by dry spells of up to 14 days, the next rain day date that is not followed by such dry spells was chosen. For computing Cessation or End dates, the formula was applied in reverse order by cumulating the total rainfall backwards from December.

Duration of the rainy season was derived by counting the number of rain days between the onset-date and the end-date of the rains in a given year. A rain day is a period of 24 hours (10:00 am - 10:00 am local time) with at least $0.3 \mathrm{~mm}$ of recorded rainfall amount. Annual rainfall total is the amount recorded for an entire year at a particular place. The study employs the mean, standard deviation and coefficient of variability in analyzing the variations in the study variables. Partial correlation and multiple linear regression analysis were the statistical tools used to establish the relationship and effect of rainfall characteristics on maize yield. The regression model for the study was also computed as:

$$
Y=a+b 1 \times 1+b 2 \times 2+b 3 \times 3+b 4 \times 4+b n \times n+e
$$

where;

$Y=$ the value of the dependent variable (maize yield/ ha);

$a=Y$ intercept

$b 1, b 2, b 3, b 4, \cdots b n=$ regression coefficients (each $\mathrm{b}$ represents the amount of change in $Y$ (Maize yield/ha) for one unit of change in the corresponding $\mathrm{X}$-value when the other $x$ values are held constant;

$x 1, x 2, x 3, x 4, \cdots x n=$ the independent variables (i.e. rainfall onset, cessation, duration, annual totals and annual number of rain days respectively); and,

$e=$ the error of estimate or residuals of the regression.

Apart from the coefficients of the independent variables (rainfall characteristics), coefficient of multiple determinations $\left(\mathrm{R}^{2}\right)$ was used to determine the percentage explanation achieved jointly by the rainfall characteristics. This method is preferred since it gives the best linear and unbiased estimates among other estimators. It has been used by several authors to effectively study the impact of climate on crop yield $[7,9,17]$.

\section{Results}

\subsection{Variations in Rainfall Characteristics}

The descriptive statistics of the rainfall characteristics shown in Table 1 indicates that the earliest date of onset of the rainy season was 20th February of 1982 while the latest date was 5th May of 1983 while the mean date was 6th April. The earliest date of cessation was 28th September of 1983, the latest date was 12th December of 1988 while the mean date was 28th October. Also, the longest duration of the rainy season was 267 days in 1988 while the shortest duration was 146 days in 1983 and the mean duration was 205 days (about 6 months and 3 weeks). The highest number of rain days was 92 days while the lowest were 51 days and the mean days were 71 days. The highest rainfall amount was $1893.6 \mathrm{~mm}$ in 1997 while the lowest was $903.6 \mathrm{~mm}$ in 1983 and the mean annual amount was $1314 \mathrm{~mm}$. On the other hand, the highest mean maize yield per hectare was $3700 \mathrm{~kg} / \mathrm{ha}$ in 1995 while the lowest yield of $610 \mathrm{~kg} / \mathrm{ha}$ was recorded in 1983 and the mean yield was $1960 \mathrm{~kg} / \mathrm{ha}$ (Table 2). The result indicates that there is a delay in the dates of onset accompanied by early cessation dates of the rainy season, shortening duration of the growing season and number of rain days, consequently declining maize yield per hectare even though high rainfall amount is received. It can also be observed that 1983 recorded the lowest yield of maize per hectare $(610 \mathrm{~kg} / \mathrm{ha})$, probably due to the latest onset date (5th May), earliest cessation date (28th September), shortest duration (146 days), lowest number of rain days (51 days) and annual rainfall amount $(903.6 \mathrm{~mm})$ that occurred in the same year.

\subsection{The Coefficient of Variability}

The coefficient of variability of the rainfall characteristics shows that onset dates of the rainy season has the highest coefficient of variability $(17.8 \%)$, followed by 
Table 1. Extreme statistics of dates of Onset and Cessation of Rain at Study Area.

\begin{tabular}{cccccccc}
\hline Variable & $\begin{array}{c}\text { Earliest } \\
\text { Date }\end{array}$ & Mean & ${ }^{*}$ LDM & Year & $\begin{array}{c}\text { Latest } \\
\text { Date }\end{array}$ & LDM & Year \\
\hline Onset & 20th Feb & 6th April & 45 & 1982 & 5 th May & 29 & 1983 \\
Date/Days & 51 & 96 & - & - & 125 & - & - \\
Cessation & 28 th Sept 28th Oct. & 30 & 1983 & 12 th Dec. & 45 & 1988 \\
Date/Days & 271 & 301 & - & - & 346 & - & - \\
\hline
\end{tabular}

* Length of Deviation from the Mean.

Table 2. Extreme Statistics of Rainfall Characteristics and Maize Yield at Study Area.

\begin{tabular}{cccccc}
\hline Variable & Mean & Highest & Year & Lowest & Year \\
\hline Duration (Days) & 205 & 267 & 1988 & 146 & 1983 \\
$\begin{array}{c}\text { Rain Days (Days) } \\
\begin{array}{c}\text { Annual Amount } \\
(\mathrm{mm})\end{array}\end{array}$ & 1314 & 1893.6 & 1997 & 903.6 & 1983 \\
$\begin{array}{c}\text { Maize Yield (kg/ha) } \\
1960\end{array}$ & 3700 & 1995 & 610 & 1983 \\
\hline
\end{tabular}

annual rainfall amount (16.0\%), annual rain days (13.8\%), duration of the rainy season (12.2\%) and the least variability of $4.6 \%$ was found in dates of cessation of the rainy season. On a general note however, the highest coefficient of variability of (39.9\%) was recorded in maize yield per hectare (Table 3). This implies that the dates of cessation were more reliable and predictable whereas the dates of onset were more unreliable and unpredictable in the study area. The highest coefficient of variability of Maize could be as a result of the joint effect by the variability in all the rainfall characteristics studied and other climatic and non-climatic factors not directly considered in this study.

\subsection{Relationship between Rainfall Characteristics and Maize Yield}

The correlations between rainfall characteristics and maize yield shows that annual number of rain days (0.747) and annual rainfall amounts (0.599) had strong (significant) positive correlation with maize yield; duration (0.306) and dates of cessation (0.219) had weak positive correlations with maize yield; while dates of onset $(-0.269)$ had weak negative correlations with maize yield (Table 4). This implies that variations in annual rain days and annual rainfall amounts account most for the annual variations in maize yield. This confirms the findings by [18] where they discovered that annual rain days and annual amount had the greatest effect on maize yield in a similar study conducted in Kwara State, Nigeria. Thus, the higher the amount of rainfall spread over the number of rain days in a year, the higher the yield of maize per hectare in the area.

\subsection{Model for Predicting Maize Yield}

The extent to which the rainfall characteristics determine variations in the yield of maize in the study area is shown in Table 5. The five (5) independent variables: Onset dates, Cessation dates, Duration, Annual rain days and Annual rainfall amounts were regressed on maize yieldthe dependent variable.

Table 3. Descriptive Statistics of Rainfall Characteristics and Maize Yield.

\begin{tabular}{cccc}
\hline Variable & Mean & $\begin{array}{c}\text { Standard } \\
\text { Deviation }\end{array}$ & $\begin{array}{c}\text { Coefficient of } \\
\text { variability (\%) }\end{array}$ \\
\hline Onset dates (Days) & 96 & 17.11 & 17.8 \\
Cessation dates (Days) & 301 & 13.81 & 4.6 \\
Duration (Days) & 205 & 24.94 & 12.2 \\
Annual Rain Days (Days) & 71 & 9.81 & 13.8 \\
Annual Amount (mm) & 1314 & 210.49 & 16.0 \\
Maize Yield (kg/ha) & 1960 & 781.74 & 39.9 \\
\hline
\end{tabular}

Table 4. Correlation Matrix of Rainfall Characteristics and Maize Yield.

\begin{tabular}{ccccccc}
\hline Variables & $\mathrm{Y}$ & $\mathrm{X}_{1}$ & $\mathrm{X}_{2}$ & $\mathrm{X}_{3}$ & $\mathrm{X}_{4}$ & $\mathrm{X}_{5}$ \\
\hline $\mathrm{Y}$ & 1.000 & & & & & \\
$\mathrm{X}_{1}$ & -0.269 & 1.000 & & & & \\
$\mathrm{X}_{2}$ & 0.219 & -0.293 & 1.000 & & & \\
$\mathrm{X}_{3}$ & 0.306 & $-0.848^{*}$ & $0.755^{*}$ & 1.000 & & \\
$\mathrm{X}_{4}$ & $0.747^{*}$ & -0.197 & 0.129 & 0.206 & 1.000 & \\
$\mathrm{X}_{5}$ & $0.599^{*}$ & -0.223 & 0.124 & 0.222 & 0.430 & 1.000 \\
\hline
\end{tabular}

${ }^{*}$ Coefficient is significant at 0.05 confidence level (2-tailed).

Table 5. Coefficients of the Regression Analysis.

\begin{tabular}{cccccc}
\hline Model & \multicolumn{2}{c}{$\begin{array}{c}\text { Unstandardised } \\
\text { coefficients }\end{array}$} & \multicolumn{3}{c}{ Standardised coefficients } \\
\hline Parameters & B & Std Error & Beta & T & Sig. \\
\hline Constant (a) & -4790.898 & 2338.32 & - & -1.830 & 0.079 \\
$\mathrm{X}_{1}$ & -2.723 & 5.566 & -0.055 & -0.489 & 0.629 \\
$\mathrm{X}_{2}$ & 5.233 & 6.749 & 0.088 & 0.775 & 0.445 \\
$\mathrm{X}_{3}$ & 9.797 & 5.627 & 0.313 & 1.741 & 0.093 \\
$\mathrm{X}_{4}$ & 48.650 & 10.106 & 0.586 & 4.814 & $0.001^{*}$ \\
$\mathrm{X}_{5}$ & 1.107 & 0.474 & 0.324 & 2.337 & $0.028^{*}$ \\
\hline
\end{tabular}

${ }^{*}$ Coefficient is significant at 0.05 confidence level. 
From the regression coefficients shown in Table 5, the regression equation or predictor model of the study was stated thus:

$$
\begin{aligned}
Y= & -4790.90-2.723 \times 1+5.233 \times 2+9.797 \times 3 \\
& +48.650 \times 4+1.107 \times 5+291
\end{aligned}
$$

where;

$Y=$ Predicted yield of maize in the area.

From the model, it means that given a unit change in any of the rainfall characteristics while holding others constant, the highest variation in yield of maize in the area will be accounted by annual rain days (48.650 $\mathrm{kg} / \mathrm{ha})$, followed by duration $(9.797 \mathrm{~kg} / \mathrm{ha})$, end dates $(5.233 \mathrm{~kg} / \mathrm{ha})$, annual amount $(1.107 \mathrm{~kg} / \mathrm{ha})$ and the least change in yield will be from onset $(-2.7233 \mathrm{~kg} / \mathrm{ha})$. These show that among the rainfall characteristics, annual number of rain days $(x 4)$ is the most important variable for the variation in maize yield in the study area indicating that the yield of maize is higher when annual number of rain days is higher. This is followed by annual rainfall totals $(x 5)$, meaning that there was higher yield of maize under years with higher rainfall amount than those with lower amount. Also, this agrees with the t-test analysis which indicates that among the rainfall characteristics only annual number of rain days ( $x 4)$ and annual rainfall amount $(x 5)$ are significant in influencing yield at 0.05 confidence level as their calculated t-test values (4.814 and 2.337) are greater than their table values of 0.001 and 0.028 respectively. Thus, the distribution of annual rainfall amount over rain days has been the major determinant of maize yield in the area. This confirms the findings by [19] that large decrease in rainfall amount leads to unacceptable low yields. Also, it has been observed by [7] in Ibadan, [20] in Zaria that annual rainfall amount has a strong influence on crop yield. The contributions of annual rain days and annual amount were followed by those of duration of the rainy season, dates of cessation and dates of onset having insignificant coefficients. It is important to note however that, the insignificance of the dates of onset in influencing yield in this case could be due to the fact that the AOCAY Farm Department plants its maize only when the rain has fully commenced. Moreover, dates of onset affects planting dates which in turn affects the yield but these were not available.

The result gave a coefficient of multiple determinations $\left(\mathrm{R}_{2}\right)$ of 0.677 which is computed to be $67.7 \%$. This means that $67.7 \%$ of the variations in the yield of maize per hectare for the past 30 years in the study area can be explained jointly by the variations in the five identified rainfall characteristics. The remaining $32.3 \%$ of the variations in the yield of maize can be attributed to other unexplained factors such as soil characteristics, farming methods, planting dates, weeds, fertilizer application, seed varieties, pest and diseases, harvesting and other rainfall characteristics/climatic factors.

\section{Conclusions}

The study has established that there is high variability in rainfall characteristics which translates into high variability in Maize yield per hectare. Additionally, there is a gradual delay in the dates of onset without a delay in the dates of cessation of the rainy seasons. This results in shortening duration/number of annual rain days. The results also reveal that number of rain days and annual rainfall amount have the strongest influence on maize yield per hectare in the study area.

To ensure that the effect of rainfall variability on maize yield is reduced and maize (and indeed crop yield) is generally enhanced at the study area, the following has been recommended:

- The Nigerian Meteorological Agency (NIMET) should issue seasonal forecasts of dates of rainy season onset and cessation, duration of rainy season and annual number of rain days each year. Considering the sensitivity of crop yields to these variables, farmers should be encouraged to avail themselves of these services and apply such information to enhance early planting and reduce yield losses attributed late planting after dates of onset;

- Agricultural Extension Officers (AEOs) should be deployed to guide farmers through routine visits, sensitization programmes on variability in rainfall characteristics, use of farm inputs and monitoring of cropclimate relationship in the area in other to achieve improved crop yield;

- Improved and/or genetically modified crop species that require less consumptive use of moisture and have shorter growing period should be made available to farmers with other incentives and they should be encouraged to grow them;

- In view of the high correlation of rain days and rainfall amount with maize yield, the need for appropriate land use management practices that will ensure moisture availability in the area has become crucial for sustainable crop production. To this extent, soil conservation and age old farm practices such as land tillage, mulching, planting cover crops, controlling and checking erosion to help protect the soil from deterioration or degradation should be adopted; and,

- Application of irrigation and growth of crops in riverine areas to supplement the water needs crops at the critical stages of growth. The reliance on rain-fed agriculture in this 21 st century by majority of the farmers exposes the neglect by government in meeting the challenge of food security. The study area and Benue State in general found unsuitable for optimum growth of maize evoked the need for supplemental irrigation 
and growth of maize along the streams and river banks to meet the moisture needs of crops.

\section{Acknowledgements}

The authors are grateful to the Farm Department and Agro-Metrological Units of AOCAY for maize yield and rainfall data, respectively.

\section{REFERENCES}

[1] FAO, WFP and IFAD, "The State of Food Insecurity in the World. Economic Growth Is Necessary but Not Sufficient to Accelerate Reduction of Hunger and Malnutrition," FAO, Rome, 2012.

http://www.fao.org/docrep/016/i3027e/i3027e.pdf

[2] R. Mendelsohn, A. Dinar and A. Dalfelt, "Climate Change Impacts on African Agriculture," In: B. Brates, Z. W. Kundewicz, S. Wu and J. Palutikof, Eds., Climate and Water, 2008.

http://www.csmonitor.com/2006/1106/p04501-woaf.html

[3] J. O. Ayoade, "Introduction to Climatology for the Tropics," Spectrum Books Limited, Ibadan, 2004.

[4] A. O. Nyong, "Climate Change, Agriculture and Trade: Implications for Sustainable Development," ICTSD, 2008. http://www.agritrade.org/events/documents/paper_Antho ny_nyong_barcelona08.pdf

[5] M. N. Igwebuike, F. C. Odoh, C. I. Ezeugwu, N. F. Oparaku and O. U. Oparaku, "Climate Chang, Agriculture and Food Security," In: R. N. C. Anyadike, I. A. Madu and C. K. Ajaero, Conference Proceedings on Climate Change and the Nigerian Environment, UNN, 2010.

[6] J. Adejuwon, "The Context of Food Security," In: J. O. Adejuwon and O. O. Ogunkoya, Eds., Climate Change and Food Security in Nigeria, OAU Press, 2010.

[7] J. O. Akintola, "An Analysis of the Effects of Agroclimatic Factors on Food Crop Yields in Ibadan Area of Oyo State," Unpublished Ph.D Thesis, University of Ibadan, Ibadan, 1983.

[8] M. Falkenmark, "Water Scarcity and Food Production in Africa," Forum for Applied Research and Public Policy, Vol. 8, No. 4, 1989, pp. 54-60.

[9] B. T. Tyubee, "An Analysis of Food Crop Yields and Climate Relations in Benue State, Nigeria," Journal of the Nigerian Meteorological Society, Vol. 6, No. 1, 2006.

[10] S. A. Ityo, "Analysis of Rainfall Distribution Pattern at Genyi-yandev, Benue State," Unpublished Research Project Submitted to the Department of Geography, Benue State University, Makurdi, 2010.

[11] J. L. Nyagba, "Geography of Benue State," In: D. I. Denga, Ed., Benue State, a Compendium, Aboki Publishers, Makurdi, 1995.

[12] W. M. Walter, "Length of the Rainy Season in Nigeria," Nigerian Geographical Journal, Vol. 10, No. 2, 1967, pp. 121-128.

[13] O. O. Ilesanmi, "An Empirical Formulation of the Onset, Advance and Retreat of Rainfall in Nigeria," Journal of Tropical Climatology, Vol. 34, 1972, pp. 17-24.

[14] P. Benoit, "The Start of the Growing Season in Northern Nigeria," Agricultural Meteorology, Vol. 18, No. 2, 1977, pp. 91-99. doi:10.1016/0002-1571(77)90042-5

[15] O. J. Olaniran, "The Start and End of the Growing Season in the Niger River Basin Development Authority Area of Nigeria," Malaysian Journal of Tropical Geography, Vol. 9, 1983, pp. 49-58.

[16] N. J. Bello, "On Reliability of the Methods of Predicting the Onset and Cessation of the Rains in a Tropical Wetand-Dry Climate: Ondo as a Case Study," Journal of the Nigerian Meteorological Society, Vol. 1, No. 1, 1995, pp. 41-55.

[17] T. O. Odekunle, I. O. Orinmoogunje and A. Ayalande, "Application of GIS to Assess Rainfall Variability Impacts on Crop Yield in Guinea Savanna Part of Nigeria," Journal of Biotechnology, Vol. 6, No. 18, 2007, pp. 21002113. http://www.academicjournals.org/ABJ

[18] I. P. Ifabiyi and O. Omoyosoye, "Rainfall Characteristics and Maize Yield in Kwara State," Nigeria.Journal of Applied Sciences, Vol. 1, No. 3, 2011.

[19] R. Lal, "Effects of Seed Bed Preparation and Time of Planting on Maize (Zea mays) in Western Nigeria," Experimental Agriculture, Vol. 9, No. 4, 1984, pp. 303-313. doi:10.1017/S0014479700010097

[20] S. C. Ado and O. E. Abinbo, "Influence of Weather on Pepper Fruit Yield in the Nigeria Savanna," In: J. S. Oguntoyinbo, J. S. Omotosho and E. E. Ekuwen, Eds., Meteorological Hazards and Development, Lagos, Kola Okanlawon, 1991, pp. 52-58. 